\title{
Tegnsætningens historie
}

\author{
NiCHOLSON BAKER
}

De ni elementære skilletegn - komma, tankestreg, bindestreg, punktum, parentes, semikolon, kolon, mellemrum og stort bogstav - forekommer os i dag så rigtige, så piberygende indoeuropæiske og $\mathrm{i}$ deres adskillende vægt og masse så naturligt egnede til at varetage deres sætningsdannende funktioner, at vi ubekymret kan formode, at kommaet har eksisteret mindst lige så længe som elektronen, og at selv om dialekter, kædeskrift og skriftbilleder bortvejres og forgår, så består semikolonet, denne fraseologiens $i$ eminent grad selvtilstrækkelige tjener, $i$ al evighed.

I virkeligheden er semikolonet en forholdsvis moderne opfindelse. Det middelalderlige skilletegn punctus versus, der har en slående lighed med et semikolon, bortset fra at det ofte hang ned under den skrevne linje, havde nogenlunde samme vægt som et moderne punktum; et andet tegn, som (i visse skriveres hånd) til forveksling lignede et semikolon, var en almindelig brugt forkortelse for forskellige latinske endelser - atque forekommer som atq; og omnibus som omnib;. Men det semikolon, som vi bruger hver dag eller time, så dagens lys med førsteudgaven af Pietro Bembos De Aetna, der blev udgivet to år efter, at Columbus kom til Amerika, og skyldes den gode håndværker Aldus Manutius den Ældre (eller en nær medarbejder) samt hans stilsikre skriftskærer Francesco Griffo. Dette tegn, meddeler dets historiker, Malcolm Parkes, var længere om at finde nåde hos sætterne end parentesen: rystende som det lyder, havde flere af de sættere, der blev sat til at arbejde med Shakespeares første folio, åbenbart ikke til fulde forstået dets anvendelse.

Selv $\mathrm{i}$ vore dage må semikolonet finde sig $\mathrm{i}$ at blive tilsidesat og forhånet. Joyce foretrak det mere attiske kolon, i det mindste i Ulysses, og også Beckett lutrede med tiden sin prosa for dette tegn, der for ham at se må have været indbegrebet af vulgær, højvictoriansk forsiring, den i støbejern udformede blomst af den masseproducerede ciceronisme: $i$ stedet for at bruge semikoloner splejsede han sætningerne i Malone dør og Molloy sammen med kommaet, der jo er lige så banalt som strandsten, for at opnå det toneleje af deklamatorisk fremmumlede depressive udsagn, der er så karakteristisk for hans fortællerstemme - alt sammen måske et led i hans bredere bestræbelse på at skrotte engelsk til fordel for fransk, "pour m'appauvrir": for at forarme mig.

Også Donald Barthelme, der har udtalt, at det var Becketts eksempel, der i sin tid "satte [ham] i stand til at skrive", mente, at semikolonet var "stygt, vederstyggeligt som en tæge på en hundevom" - men erkendte dog, at andre kunne have en anden mening. Og semikolonet har overlevet, da det åbenbart har vist sig at være alt for nuanceret og anvendeligt til at lade sig afskaffe af modernismen. Det indgår endda i de nyeste former for emotionel tegnsætning, der betegnes som "smileys" eller "emotikoner" lettere idiotiserende forsøg på at angive en slags ansigtsudtryk $i$ afslutningen af sætninger i en e-mail f.eks., :-) eller >\%-(. Semikolonet medvirker også til at skabe et "blink" eller et "grin", således - ;-).

Vores bekendte og yderst anvendelige tegnrepertoire har med andre ord været længe om at vinde frem; det har udviklet sig fra et virvar af indbyrdes konkurrerende og overlappende systemer og teorier, der i mange tilfælde har været forkert anvendt eller er blevet mangelfuldt fremdraget af glemmebogen. Petrarca brugte således en skråstreg med et punktum midt på for at angive begyndelsen på en parentetisk sætning. Et percontativus, et bagvendt spørgsmålstegn, blev undertiden, helt indtil det I7. århundrede, benyttet for at markere afslutningen på et retorisk 
spørgsmål - Robert Herrick skrev med det. Et punctus elevatus, der ligner et omvendt semikolon og senere et gotisk $s$, gjorde tjeneste som kolon i mange tekster fra middelalderen; når det blev anbragt som afslutning på en verslinje, kunne det til gengæld angive et enjambement. Et navnløst tegn af form som en skråtstillet sukkerstang blev anvendt til at markere sætningsafslutningerne i Augustus' selvbiografi (fra $\mathrm{r}_{4} \mathrm{f}$. $\mathrm{Kr}$.) og er foreviget på hans gravmæle. Omkring 600 e. Kr. foreslog Isodorus af Sevilla, at sætninger burde afsluttes med et 7, som han kaldte en positura. Han anbefalede ligeledes brugen af en vandret streg ved siden af et forvansket eller tvivlsomt tekstafsnit ("så at en slags pil kan skære halsen over på det overflødige og gennembore det falskes indvolde"), og han benyttede sig også af det gamle cryphia, et $\mathrm{C}$ anbragt på ryggen med en prik i favnen, ved siden af de steder $i$ en tekst, hvor "et vanskeligt og dunkelt spørgsmål ikke lader sig udrede eller besvare".

Det opretstående C, der står for capitulum, udviklede sig til det i middelalderen bredt anvendte sætningssymbol, ๆ, undertiden kaldet paragraftegn eller alinea. Det 7. århundredes irske kalligrafer havde for vane at bruge flere punktumer, når de onskede at angive en længere pause; en sætning kunne således afsluttes med et kolon og et komma (:,) eller med to punktumer og et komma (..,) eller med tre kommaer (,,,). Sidst $\mathrm{i}$ det $\mathrm{I2}$. århundrede foreslog en af udøverne af ars dictaminis, en mand ved navn Buoncompagno, som åbenbart var træt af de mange indviklede og uforenelige tegnsystemer, at systemet burde forenkles: en tankestreg skulle markere alle afsluttende pauser, mens en skråstreg skulle angive kortere pauser. Det slog ikke an, men den "dobbelte virgula" (//) blev dog brugt til at adskille sætninger i det I5. århundrede, og Edmund Spenser og Walter Raleigh benyttede undertiden håndskrevet enkelt skråstreg i stedet for komma. Plustegnet (+) betegner et punktum i nogle få af de første trykte bøger; $i$ andre indleder det somme tider et citat.

Bogtrykkerkunsten bevirkede med tiden, at den fri opfindsomhed fik dårligere kår, og at mange løjerlige overflødigheder forsvandt, men nye tegn og overraskende anvendelser af gamle kan aldrig helt udelukkes. Bortset fra smileyer har internettet på det seneste affødt den henrykte omklamring angivet ved: $\{\{\{\{\{\{\{$ Shana!!! $\}\}\}\}\}\}\}$. Juridisk definerede tegn trives også $\mathrm{i}$ bedste velgående - ${ }^{\mathrm{TM}}$, () og (C) forekommer alle vegne. (Titlen på Jurassic Park er ikke Jurassic Park, men Jurassic Park ${ }^{\mathrm{TM}}$; og det samme gælder David Feldmans Why Do Clocks Run Clockwise and Other Imponderables ${ }^{\mathrm{TM}}$.)

Mindst lige så moderne er servicemærket SM, som i "Har du glemt noget?SM" - som jeg for ikke ret længe siden så på et plasticskilt ved siden af håndvasken $i$ et værelse på en Holiday Inn: et tegn, som ændrer indholdet i den sætning, det er efterstillet, på følgende måde: "Hensigten med dette høflige spørgsmål er ikke kun at få dig til at tænke på, om du nu også har været forudseende nok til at få alle de ting med i kufferten, som du făr brug for under dit ophold her på hotellet, men også at henlede opmærksomheden på vores netop lancerede landsdækkende reklamekampagne, og vi tager spørgsmålet så alvorligt, at vi desværre er nødt til at indskærpe, at hvis du eller nogen anden forsøger at gøre noget tilsvarende over for andre gæster $i$ hotelbranchen, enten $\mathrm{i}$ trykt eller anden masseproduceret form, det være sig løbesedler, plakater, skilte, blikmærker eller plasticmærkater anbragt ved siden af håndvaske, spejle eller andet VVS-udstyr på badeværelser, vil vi, som har ophavsretten til dette servicemærke, tage alle juridiske midler $i$ anvendelse for at sagsøge dig." Selv det trofaste gamle komma bliver ved med at udvikle sig: det blev vendt på hovedet og forvandlet til anforselstegn i cirka r7r4, og en pige, jeg engang kendte på college, brugte en ganske særlig tegnsætning i sine breve til gamle skoleveninder, idet hun klippede fotografier af skævslatne mandlige kønsorganer ud af Playgirl og brugte dem som hjemmelavede kommaer.

Indtil nu har den interesserede læser været henvist til at stille sin sult efter historiske kendsgerninger om dette opslugende prosaiske emne ved at læse videnskabelige fremstillinger som $\mathrm{E}$. Otha Wingos sobre Latin Punctuation in the Classical Age eller John Lennards usædvanlige monografi om parentesens historie, udgivet for nylig under titlen But I Digress (r99r) - for øvrigt en perle af lærdom fra Oxford 
University Press, velskrevet, lysende af intelligens, forsynet med hele det akademiske inventar af registre, bibliografier og fodnoter, og åbenbart skrevet af en mand, som det fremgår af teksten under det forbløffende foto på smudsomslaget (kronraget hoved med opretstående central proto-Mohawk-bræmme, ørering i venstre øre, slatten fløjlsjakke og forvasket t-shirt med uransagelige insignier), der tjente til sine videregående studier som billethøker til Elvis Costello-koncerter. (En gennemgang af Elvis Costellos anvendelse af parentesen $i$ "Let Him Dangle" finder man i et af de sidste kapitler).

Endelig er der sandelig også Pause and Effect, Malcolm Parkes' uforfærdede fremstilling af emnet: "en introduktion," som han beskedent kalder sit værk i undertitlen, selv om det er langt mere end en introduktion, "til den vestlige verdens tegnsætning." Ikke Det fjerne $Ø$ sten, bedes man bemærke, heller ikke nogen anden verdensdel - reglerne for arabisk, græsk eller sanskrit må stadig afvente den endegyldige totalbehandling. (Ifølge MLA-indekset kan man også med fordel opholde sig ved Nanette Twines artikel fra $\mathrm{I} 984$ om "Anvendelsen af tegnsætning i japansk skrift" i Visible Language, et tidsskrift, som $\mathrm{i}$ den senere tid har påtaget sig den spændende opgave at udbrede kendskabet til tegnsætningens fortid; for den, som ønsker at udvide den vestlige verdens kanon, er der Jobn Duitsmans "Punctuation in Thirteen West African Languages" og Carol F. Justus' "Visible Sentences in Cuneiform Hittite"). Ordspillet i titlen giver løfte om en vis slagfærdighed, men hvad Malcolm Parkes - der er ansat ved Keble College og lektor i palæografi ved universitetet i Oxford - har skænket os, er et fyldigt, komplekst og decideret uslagfærdigt værk af sofabordsdimensioner og med fireoghalvfjerds farveillustrationer samt ordliste, men desværre ikke noget index rerum.

Det er ikke nogen nem bog at læse i sengen. På grund af det store folioformat når linjerne på siden et par centimeter længere ud end normalt, og resultatet er øjenbevægelser, der må overskue fjorten ord ad gangen i stedet for de mere behagelige ti eller elleve. Når læserens skuldermuskler bliver trætte af at bære den åbne bogs fulde vægt, lægger han sig om på venstre side og lader bogen synke ned på madrassen, hvor den antager L-form, og forsøger derefter at bearbejde teksten med kun ét øje, som i stedet for at afsøge ordene fra venstre til højre må læse ved at fokusere udad langs en stærkt forkortet satslinje, der næsten befinder sig parallelt med synslinjen, så han enten må springe over eller gisne sig til de ord, der forsvinder op over bogsidens mildt duvende bakkedrag. Desuden bliver mellemrummene mellem ordene mindre, til skade for tilegnelsen, selv om der aldrig bliver tale om det ubegribelige græske ideal for sidelayout, der betegnes scriptio continua, hvor teksten præsenterer sig uden mellemslag som linjer af tætpakkede bogstaver.

Hvorfor forkastede grækerne egentlig en så fornuftig praksis som ordmellemrum, når selv kileskriftens fædre på det minoiske Kreta åbenbart brugte dem? Lejeune og med ham flere andre finder denne udvikling "remarquable"; men det er en endnu mere remarquable kendsgerning, at de pragmatiske romere faktisk var bekendt med ordmellemrum (takket være etruskerne) i form af "interpunktering", dvs. punktumer der svævede mellem hvert eneste ord (en praksis der med held blev genoptaget af firmaet Wang, en producent af tekstbehandlingsprogrammer, i I980'erne), men at de opgav denne praksis tidligt $\mathrm{i}$ den kristne tidsregning. "Som forklaring på dette forbløffende og yderst beklagelige tilbageslag tør man ikke driste sig til andre hypoteser, end at de må have næret et malplaceret ønske om at efterligne græske manuskripter, selv når disses mangler var allermest påfaldende," harcelerer Revilo P. Oliver. Malcolm Parkes fremsætter til gengæld den teori, at klasseforskellen mellem læsere og skrivere kan have haft noget at gøre med bevarelsen af scriptio continua - skriveren var slave og skulle ikke formaste sig til ordmellemrum eller tegnsætning i det hele taget, idet han derved påtvang arbejdsgiveren $\sin$ personlige fortolkning af de konstitutive bogstaver. I munkeklostrene blev der fremført pseudo-mystiske argumenter for at bevare den mellemrumsløse uudgrundelighed: en genstridig tekst, der kun langsomt åbenbarede sin bogstavelige mening, gav anledning til meditation og udenadslære, mente Cassian (en fremtrædende eneboer fra det 5 . 
århundrede); og når det øjeblik omsider indfandt sig, efter megen forgæves stirren, da den afskrækkende ordgåde på den hellige side omsider gav mening og flød sammen til begribelige enheder i psalteren, kunne det tjene til at minde den henførte læser om læsehandlingens under, som er utænkeligt uden Guds kærlige nedstigning til menneskeligt sprog og menneskelig skikkelse.

De talrige fylogenetiske oplysninger til trods omtaler Parkes ikke og bør heller ikke nødvendigvis omtale det mere verdslige udviklingsmæssige faktum, at scriptio continua løber børn ganske naturligt $\mathrm{i}$ pennen:

\section{KAEREANDREAS \\ TILLYKKEMED \\ FØDSELSDAGE \\ NKAERLIGHILS \\ ENFRAKAREN}

Børn larer ikke at udelade ordmellemrummene; alle deres skriftlige forbilleder er korrekt skrevet. Som en indrømmelse til modtageren (eller den voksne iagttager) indsætter de somme tider en skråstreg hist og her for tydelighedens skyld. Der er måske noget så spændende ved at skrive, at civilisationer $\mathrm{i}$ deres vorden, endnu kun i færd med at opdage eller genopdage skriftens glæder og traditioner, i lighed med de knap femårige skal have lidt tid, før de begynder at tænke på læseligheden - som følge heraf siges de skriftkloge da også at studere litterae, "bogstaver", ikke ord

Til dels som følge af linjen uden ordmellemrum har man fra første færd opfattet skillepunkter både som en slags ornamentering og et middel til at opnå entydighed, som Parkes kalder det. Cassiodorus, den første store bibelske pointillist, rådede det 6 . århundredes munke til at tilføje interpunktionstegn "for at gøre det synligt, at teksten er udsmykket". Alcuin skrev til Charlemagne, at "distinctiones eller subdistinctiones angivet ved punkter kan forskønne sætningen overmåde". Læsere $\mathrm{i}$ den tidlige middelalder såsom Dulcitius af Aquino dekorerede under læsningen bogen med punkter, dipler og alineae og underskrev sig derefter stolt nederst på siden: “Jeg
Dulcitius har læst dette.” Tegnsætning synes i lighed med randbemærkninger eller interlinearnoter at have været en slags modydelsesritual, en erkendtlig hyldest til den tekst, som havde åbenbaret sin mening for læseren.

Noget overraskende viser det sig, at den skolastiske filosofis æra i det I3. og I4. århundrede, der, som Francis Bacon fordømmende har bemærket, var et altomfattende, indviklet spindelvæv skabt af Aristoteles, "beundringsværdigt for trådens finhed og tilvirkning, men blottet for substans og udbytte" og således den ideelle genstand for dekoration og manierisme snarere end funktionalitet, drevet frem af logik og disputationslyst, men ikke trukket af sand erkendelse - sådan set netop en tidsalder, hvor man skulle forvente, at tegnsætningen ville have særligt gode kår - i virkeligheden var en mørk og trist epoke for subdistinctiones. Parkes forklarer det med, at det skolastiske manuskripts paradigmatiske karakter, dets hyppigt gentagne queritur og questio, der meddelte læseren nøjagtigt hvor han befandt sig $\mathrm{i}$ argumentationens formelle struktur, overflødiggjorde en mere nuanceret interpunktion.

Det er selvfølgelig også muligt, at skolastikerne, som dagen lang sad og læste grufulde latinske oversættelser af arabiske tekster, der igen var oversat fra oldgræsk, ikke havde noget sprogøre. Selveste Cicero omfattede tegnsætning med foragt, idet han hævdede, at den veltempererede sætning af sig selv ville afsløre sine kadencer og termini, og at der således ikke var brug for ligegyldige "tegn indsat af en kopist"; men dem, der siden hen tog både tegnsætning og Cicero alvorligt - Cassiodorus, Isidorus, Bembo og Petrarca - røbede deres tilhørsforhold netop ved anvendelsen af skråstreger: ligesom arkaiserende komponister, der ønsker at sikre sig en tidligere tids praksis for udførelsen, og derfor anfører hvert eneste vibrato og ritenuto, selv om de historiske forbilleder kun har nedfældet noder uden tegn, kunne disse beundrere høre de usynlige skilletegn $i$ den ciceronianske sætningsrytme og $\mathrm{i}$ visse tilfælde efterligne de malmfulde effekter i deres egne skrifter, men de turde ikke løbe an på, at deres samtidige ville være $\mathrm{i}$ stand til at opdage en klassicistisk clausula uden øjets hjælp. 
Malcolnn Parkes' prosa er tjenlig og uaffekteret, men der er ikke megen flugt over den. Til glæde for alle, der aldrig fik et nært forhold til latinen, har han oversat de mange latinske citater. Han gør sig den ulejlighed fra tid til anden at omtale den politiske baggrund i det omfang, den får konsekvenser for tegnsætningens verden: hvis en katastrofe eller samfundsomvæltning resulterer $i$ "en situation til ugunst for den grammatiske kultur”, så får læseren det at vide. Man må dog undre sig over, hvor forsømmelig Parkes - denne skarpøjede palæograf, der har gjort en så stor indsats for at "højne læserens bevidsthed om, hvad tegnsætning er og kan bruges til"! - er med sine kommaer. Hvor er de blevet af? "Pausering var derfor af betydning for læsehandlingen men ikke for afskrivningen." "Inden bogtrykkerkunstens opfindelse overlod forfatteren sin tekst til skrivernes forgodtbefindende." "Trykprocessen stabiliserede ikke kun symbolernes form og funktion men styrkede også de allerede eksisterende regler for deres anvendelse." Og: “Denne forøgelse af antallet af distinktive symboler fremmede desuden en ny udvikling i sprogbrugen eftersom symbolerne ikke kun gjorde det nemmere for læseren at genkende de grammatiske elementers funktion i den enkelte sætning men også muliggjorde en finere nuancering i formidlingen af tekstens indhold."

Havde det ikke været for Parkes' usvigeligt sikre kommatering andetsteds i teksten, kunne man næsten tro, at han havde noget tilfælles med den slags psykoterapeuter, der har valgt metier ud fra en dybt rodfæstet fornemmelse af, at der er noget galt med deres egen psyke, eller med de humørforladte mennesker, der køber bøger fulde af vittigheder eller melder sig til et komikerkursus $i$ håb om at rette op på et medfødt humørunderskud. I en kommentar til en fascinerende bogside af Richard Hooker tilsidesætter Parkes eller den person, med hvem han har delt "korrekturens tunge byrde" (som han glimrende udtrykker det $\mathrm{i}$ forordet), tilmed det ellers ukrænkelige opremsningskomma:

Det tegnsystem der er benyttet til at angive gloser noter og citater i marginen, og som er baseret på rækkefølgen $i$ alfabetets bogstaver, blev også anvendt i Genferbibelen fra Is60.
Et enkelt sted overrasker Parkes til gengæld ved ubevidst at benytte det gammeldags engelske thatkomma fra det 18 . århundrede. Det er det komma, som Gibbon brugte:

Det er blevet beregnet af de kyndigste politikere, at ingen stat uden meget snart at gå sin undergang i møde kan have mere end en hundrededel af sine borgere gående som våbenføre lediggængere.

Og hos Gibbons forbillede, Montesquieu, i Nugents oversættelse fra I750 (tre gange):

Platon priste guderne for, at han var født i samme tidsalder som Sokrates: og jeg for min del kan takke den almægtige for, at jeg er født som undersåt $i$ det rige, der nu engang er mit hjem; og at det er ham velbehageligt, at.jeg adlyder dem, som han har lært mig at holde af.

Og hos Burke (to gange):

Mr. Hume fortæller mig, at Rousseau i egen person har betroet ham det hemmelige princip for sine kompositioner. Denne skarpsindige, om end excentriske iagttager har forstået, at vil man fange og fastholde offentlighedens bevågenhed, må man frembringe noget forunderligt ...

Og hos Burkes begavede modstander Thomas Paine:

Hvis det erkendes, at statsmagten er et produkt af menneskets visdom, følger det nødvendigvis heraf, at arvefølgen og de nedarvede rettigheder (som de betegnes) ikke har nogen plads $i$ den, eftersom det er umuligt at gøre visdom arvelig.

Parkes skriver: “Tegnsætningen i manuskriptet er blevet så frit bearbejdet og redigeret af senere kopister, at det ikke er særlig nemt at afgøre, om nogen af de øvrige ekfonetiske tegn også skyldes den oprindelige ophavsmand eller er senere tilføjelser." Den eneste anden skribent, jeg kan komme i tanker om, der også anvender det gammeldags that-komma med en vis konsekvens, er Peter Brown, der ligesom Parkes bruger det meste af sin tid på latinske quodsætninger, der er blevet interpunkteret af forrige ti- 
ders tyske kommentatorer. (Der sættes stadig som hovedregel komma foran dass-sætninger på tysk).

En anden ejendommelighed i Parkes' bog, muligvis den første af sin art, er forekomsten af de to halvdele af semi-kolon forbundet ikke med en bindestreg, men med en fuldvoksen tankestreg: semi-kolon. Denne forlængelse kan måske være udtryk for Parkes' personlige oprør mod amerikanske tekstredaktørers opfattelse af retskrivning, som tilsiger dem at skrive ordet helt uden adskillelse af elementerne: semikolon. Det er sandt nok, at tekstredaktører i Amerika befinder sig $i$ en tilstand af demoraliseret forvirring med hensyn til, hvilke ord der skal skrives med eller uden bindestreg - jeg er i det mindste demoraliseret og forvirret efter netop at have gennemlæst et romanmanuskript, hvori en klog óg elskværdig redaktør har slettet omkring to hundrede af mine troskyldigt anbragte bindestreger. Jeg måtte skrive "stet bindestreg" [latinsk "stet", 3. pers. sing. præs. konj. af "stare": "lad det stå"] i marginen så mange gange, at jeg til sidst forkortede det til "SB" - men der var ikke den mindste skadefryd i min stædighed: jeg ønskede ikke at opføre mig som den typiske prosaprimadonna, der kun er ude på at gøre livet besværligt for redaktøren.

Jeg mindes dog et tidligere manuskript, hvor en episode finder sted på bagsædet (i.e. the back seat) af en bil: i den indbundne andenkorrektur fandt den samme begivenhed sted på bagsædet (the backseat). I min taknemmelighed over hundrede andre småting, der ganske korrekt var blevet rettet, og da jeg ikke ønskede at virke stædig, havde jeg fromt affundet mig med denne sammenskrivning, men senere blev jeg knotten over den og besluttede i sidste øjeblik at skille ordet ad igen. ("Backseat" beder om at blive læst som en trokæ', BACKseat, ligesom "baseball", men normalt giver vi de to halvdele af et således sammenskrevet ord samme betoning i daglig tale). Med dette $\mathrm{i}$ tydelig erindring stettede jeg mig til bevidstløshed $\mathrm{i}$ det nye manuskript. Jeg stettede således re-enter (i stedet for reenter), post-doc (i stedet for postdoc), foot-pedal (i stedet for foot pedal), secondhand (i stedet for secondhand), twist-tie (i stedet for twist tie) og pleasure-nubbins (i stedet for pleasure nubbins).
Da tekstredaktørens begavelse gav hende overskud til at være udogmatisk, og da det trods alt var min bog, lod hun mig på godt og ondt fă min vilje. Undervejs $\mathrm{i}$ forløbet havde vi en stimulerende drøftelse af ordet pantyhose, som hun havde rettet til panty hose. Min anskuelse var, at ordet hose nu ikke længere anvendes som betegnelse for en strømpe, og at man kun kan forestille sig ordet panty $i$ entalsformen som en del af pantywaist eller som sætningselement $\mathrm{i}$ et hypotetisk katalog fra L.L. Bean: "Bean's finest chamois-paneled trail panty." Pantyhose danner med andre ord en enkelt, sammensmeltet betydningsenhed, der er større end summen af sine dele, og det burde faktisk være kriteriet for en sammenskrivning. Men selv om det foreslåede ordmellemrum efter min mening var en fejl, kunne jeg sagtens have affundet mig med både panty-hose og pantyhose - faktisk ville jeg under normale omstændigheder have agiteret for anvendelsen af en bindestreg $i$ denne forbindelse, eftersom de magtfiuldkomne retskrivningspolitikere hos Merriam-Webster og redaktørerne af Words into Type i de senere år har læst alt for meget Joyce og forvandlet ord til klyngehuse (især sammensætninger med -like, der undertiden ligner bogstaveret japansk, når de er sammenskrevet), skønt de fortjener parcelhusværdigheden. (Man kan mene, at Joyce tilstræbte en prosa, der skulle være anderledes, irsk, fremmedartet, ikke pyntet med pernittengrynede Oxford-bindestreger, der så at sige tog på de grovkornede ordklumper med sarte behandskede fingre: det ville have gjort ham ondt at se idiosynkratiske nydannelser som cuffedge (skjortemanchet) og watchchain (urkæde) og det navnkundige scrotumtightening (scrotumstrammende) gøre tjeneste som forbilleder for amerikanske retskrivningshyrder). En bindestreg med smagfuld elastik ville have været helt i sin orden i pantyhose, hvisker min forvirring til mig nu, for så vidt den scrotumstrammende kunne have trukket ordet på plads i skridtet.

Disse personlige betragtninger tjener til at illustrere, hvor små de momenter er, som kumulativt resulterer $\mathrm{i}$ interpunktionel berøringsangst. Evolutionen skrider frem fra bindestreg til bindestreg og fra manuskript til manuskript - drevet af spændinger 
mellem arbejdende forfattere og deres tekstredaktører og mellem arbejdende tekstredaktører og deres opslagsværker ("Jeg ser lige efter engang i den store Web," sagde en munter tidsskriftsredaktør engang til mig); samt af beundring for forgængerne og den altid overhængende fare for at blive lam af kedsomhed. Er de tegn, vi bruger lige nu, virkelig tilstrækkelige? Kan man ikke somme tider mærke en brat mavekrampe af afsky, når man lader ojet glide ned over en trykt side og ser en hel masse nydelige små indskudte sætninger (naturligvis kun én pr. hovedsætning: Chic. Man. St. S 5.91) fremhævet af nuttede små prunkløse og parvist anbragte tankestreger?

I det I9. århundrede mente man ikke på nogen måde, at en isoleret tankestreg kunne gøre fyldest. Malcolm Parkes afslutter sin fremstilling af "Romanforfatterens mimetiske ambition og udnyttelsen af skriftmediets pragmatik" med Virginia Woolf, og han kan derfor tilgives, at han ikke behandler den isoleret set største omvæltning i det 20. århundredes tegnsætning, nemlig de store tankestregshybriders undergang. De har alle tre - komma-stregen,-, semistregen ;- og kolon-stregen :- (jeg betegner dem således for at lette analysen) - den allerstørste betydning for victoriansk prosa, men er ligeledes alle tre uddøde nu (bortset fra de museumseksemplarer, der omtales nedenfor).

Alle forfattere anvendte tankestregshybrider. Man finder dem hos Dickens, Wilkie Collins, Charlotte Brontë og George Meredith. Og på næsten hver eneste side hos Trollope:

Af navn var han ikke alene arving til, men også i bogstavelig forstand ejer af en stor landejendom; - men han kunne ikke røre kapitalen og af dens afkast kun så meget, som visse juridiske gnavpotter gav ham lov til. Som Greystock havde sagt, lå gud og hvermand i søgsmål mod ham, - så godt var det lykkedes hans far at fejlbestyre, fejlvurdere og fejlbehæfte ejendommen.

Skriver man for hurtigt, fører det uvægerligt til manglende precision,- - hovedsagelig fordi øret, hvor hurtigt og pålideligt det end måtte opfatte, undertiden bryder sammen under for stort et pres, og allerede inden en sætning er afsluttet har glemt den nærmere karakter af den komposition, som den indledtes med.

Romaner skrevet af en mand med en så særegen tankegang må nødvendigvis blive ejendommelige, - og ejendommelige er de blevet.

Man finder dem hos Thackeray:

[...] kaptajnen var ikke alene uvant med at sige sandheden,han var end ikke i stand til at tænke sig til den - sandhed og opspind flød sammen $\mathrm{i}$ hans omtågede, whiskyhærgede hjerne.

\section{Og hos George Eliot:}

Den almindelige opfattelse var, at det "meste" ville tilfalde Fred Vincy, men hos Vincys vakte det overraskelse, da det blev bekendt, at titusind pund investeret i værdipapirer var testamenteret til ham:- skulle han også have jorden?

Også de mest toneangivende prosenkreuzere - De Quincey, Carlyle, Ruskin, Newman og Doughty benytter sig uafladeligt af streghybrider, ofte i retoriske stjernestunder:

Det er et gode at være en gentleman, det er et gode at have dannelse, god smag, en velvillig, ligevægtig og upartisk forstand, en værdig og høvisk optræden i omgangen med andre; - disse egenskaber er den naturlige følge af en omfattende viden; de er det mål, som universitetet stiler imod: jeg er deres fortaler, og jeg agter at slå til lyd for dem og insistere på dem; men jeg må stadig gentage, at de ikke èr nogen garant for fromhed eller blot retskaffenhed, for de kan lige så vel forefindes hos verdensmanden, den udsvævende, den hjerteløse,- - så behagelig, desværre, og tiltalende, som han måtte være, når han kan rose sig af dem.

Skønt Walter Pater har vææret anklaget for en overdrevent fuldtonende purisme og ubestrideligt også undertiden tager lidt let på forfattelsen (for at stjæle en vending fra Arsenio Hall), bruger han den interpunkterende pardannelse som middel til at sammenkæde sit fabelagtige essay om litterær stil og i de afsluttende bemærlainger til The Renaissance. Og 
Sydney Smith har skrevet, at hvis Francis Jeffrey en dag havde fået til opgave at anmelde solsystemet Francis Jeffrey var den sure anmelder, der skrev "Det duer ikke til noget" om Wordsworths Excursion - ville det have lydt: "Dårligt belyst - planeterne alt for langt væk - skæmmet af kometer uopfindsomt; - kunne meget nemt have været bedre." Emerson var en ihærdig bruger af semi-stregen; af de tooghalvtreds tankestreger i "The American Scholar" er der i henhold til min optælling kun fire, som ikke er ledsaget af enten semikolon eller komma.

Efter århundredeskiftet bliver hybriderne noget mindre almindelige, selv om det stadig er forholdsvis nemt at finde dem. Henry James brugte nogle stykker $\mathrm{i}$ sine første romaner, men bortredigerede dem i den édition de luxe, der begyndte at udkomme i I907. I Encyclopaedia Britannica fra I9II, en god prøvesten for edwardianske normer, anvendes de ganske hyppigt:

En større skrue kan imidlertid underkastes en foreløbig prøve på følgende måde:-(I) Undersøg om skruegangens vindinger er lydefri og uden grater ... (2) Fastspæend skruen centreret i pinolen på en drejebænk ... (4) Læg mærke til om møtrikken løber fra den ene ende af skruegangen til den ánden uden at vrikke, når skruen roteres, og møtrikken forhindres $i$ at følge med. Såfremt møtrikken slingrer, siges skruen at være fuld.

Og i Father and Son fra 1907 benytter Edmund Gosse en dejlig komma-formildet tankestreg, der kan tolkes som et vemodigt farvel til en tegnsætningsskik, der havde kendt bedre dage:

Disse klippepytter, som er omkranset af koralalger og fulde af stillestående vand, der er næsten lige så krystalklart som de øvre luftlag, og myldrer af smukke, levende organismer,- de findes ikke mere, for de er alle sammen skændede og tømte og forsimplede.

De dukker også op hist og her hos Norman Douglas, den unge J.B. Priestley og Cyril Connolly. J.M. Keynes anvendte et bredt udvalg af alle tre former $i$ sin afhandling fra 1920 , Economic Consequences of the Peace. Et eksempel:
Bestræbelsen på at reducere Tysklands opvoksende generation til trældom, på at forringe flere millioner menneskers vilkår og berøve en hel nation udsigten til livslykke, burde vakke harme og afsky, - harme og afsky, også selv om det var muligt, også selv om det kunne berige os, også selv om det ikke såede kimen til fordærvelse for alt civiliseret liv i Europa som helhed.

Den hybride tegnsætning var allerede dømt til undergang. Proust brugte to kolon-streger i den enorme sætning om "mit livs soveværelser", der indleder På sporet; Scott Moncrieff slettede dem i sin efterkrigsoversættelse fra I922. (Terence Kilrnartin, den brave mand, re-etablerede den oprindelige tegnsætning i I98I). Den mest dandificerede dandy af alle forfattere, Vladimir Nabokov (der vistnok læste Father and Son lige så grundigt, som han læste Proust, draget hertil af dens charmerende blanding af litteratur og naturinteresse) brugte over tres velanbragte komma-tankestreg-pardannelser i sin første og ganske edwardianske engelsksprogede roman The Real Life of Sebastian Knight (I94I). Et eksempel: "En titel," sagde Clare, "bør formidle en bogs kulør,ikke dens emne." Han brugte slet ingen i Speak, Memory: The New Yorker havde pillet dem ud af ham. I alle hans senere værker har jeg kun fundet én kostelig semi-tankestreg: Humbert skriver: "Jeg mindes, da operationen var overstået, helt overstå̉et, og hun brast $\mathrm{i}$ gråd i mine arme; - en sund og gavnlig syndflod af tårer efter et af de anfald af humørsyge, der var blevet en vane for hende i løbet af dette ellers så fortræffelige år!"

Endnu mere dyrebare for tegnhistorikeren er de to eksempler på omvendte komma-streger, man kan finde $\mathbf{i}$ Updikes tidlige romaner - det ene $\mathbf{i}$ forlaget Fawcetts udgave af The Centaur, det andet på side 22 i Fawcett-udgaven af Of the Farm:

Mens Joan trøstede drengen, forklarede min mor, stadig med yardstokken - orangegul og med en mærkat fra isenkræmmeren Alton-, i hånden, at han havde "gjort øjne til hende" hele formiddagen og $i$ længere tid haft planer om at "sætte hende på prøve".

$$
\tau
$$

Denne ualmindelig sjældne variant kan føres tilbage til H.L. Mencken i r940'erne - 
Min far lod installere et dampdrevet centralvarmeanlæg sidst i firserne - det første på Hollins Street-, men det hørte til sjæeldenhederne indtil et godt stykke ind i det næste århundrede.

Og tilbage til Proust: “Que nous l'aimons - comme en ce moment $\mathrm{j}$ 'aimais Françoise-, l'intermediaire bien intentionné qui" etc.

Men Updike, vores bannerfører, drager aldrig i felten for komma-streger nu om dage. De bliver end ikke brugt i John Barths pastiche på I80o-tallets stil, The Sot-Weed Factor, hvor de ellers ville have været på deres plads. (Man kunne finde dem alle vegne også $\mathrm{i}$ det $\mathrm{I}$ 8. århundrede). Hvad var det for en komet eller gletsjer, der fik dem til at uddø? Dette er måske vor tids største litterære spørgsmål. Jeg forsøgte spagfærdigt at bruge en semikolon-streg i et essay til The Atlantic Monthly i 1983: resultatet var en underlig snurrende lyd i halsen på redaktøren, en måde at angive det utænkelige på, og jeg strakte omgående våben. Hvorfor er de dog forsvundet? Skyldes det - man forsøger sig jo altid med en McLuhan-inspireret forklaring først - den stadig mere udbredte brug af skrivemaskinen og dermed et tastatur, hvor komma-, kolon- og semikolon-tasterne er anbragt på en sådan måde, at det er fysisk akavet at anslå bindestregs-tasten umiddelbart efter et af de andre skilletegn? Eller skyldes det måske man leder jo altid efter en pseudo-videnskabelig forklaring umiddelbart efter McLuhan - kvantemekanikkens uhindrede sejrsgang? Et komma er ubestrideligt mere kvanteagtigt end en komma-tankestreg. Resulterede dadaisternes og E.E. Cummings' punktumlege eller det sidste, tegnløse kapitel i Ulysses i et simpelt overherredømme, der kunne kvæle ethvert oprør?

Sprogbrugsmanualerne har altid haft svært ved at få plads til den hybride tegnsætning - hvilket er forståeligt, eftersom den vanskeliggør et systematisk regelsæt. Den mest indflydelsesrige victorianske antibarbarus, John Wilsons $A$ Treatise on English Punctuation, der blev udgivet i noget nær tredive oplag i både England og Amerika, tolererede blandede skilletegn; i senere udgaver var der endog tilføjet sider med både skriftlige og mundtlige øvelser, som sigtede på at hjælpe den interesserede frem mod for- øget behændighed med komma-stregerne. Men “"en ganske unødvendig overflod af rette linjer," advarede Wilson, som andre havde gjort det før ham, “især på den trykte side, er et brud med den gode smag og vidner om stregbrugerens store ukendskab til tegnsætningens kunst ..." I "Stops" or, How to Punctuate var Paul Allardyce, Wilsons edwardianske efterfølger, noget mere streng: "Der er sjældent anledning til at bruge dobbelttegn." G.V. Carey, forfatteren til Mind the Stop, ytrer sig entydigt: "Kombinationen af andre skilletegn og tankestreg er endnu mindre tilladelig, end når de anvendes sammen med klammer." Det lysnede en smule med Eric Partridges You Have a Point There (I953) - han tillod minsandten brugen af kombinerede skilletegn, dog med "måde og varsomhed", og havde også mod til at indrømme, at de "undertiden var uundgåelige".

Men det var i I953 i et fejltolerant England. Ifølge The Chicago Manual of Style (\$ 5.5) er tankestregshybrider for tiden lovstridige i USA. I biodiversitetens navn tillod jeg mig dog at indføje et par stykker af dem på upåagtede steder $\mathrm{i}$ min første roman, trods redaktørens indvendinger, i 1988 . Jeg troede, at jeg skabte historie. Men som det viste sig, var Salman Rushdie kommet mig i forkøbet: i De sataniske vers, der udkom et par måneder fơr min roman, er der brugt snesevis af komma-streger, og de er tilmed brugt aggressivt, fandenivoldsk, mere i stil med Laurence Sterne end med Trollope. Brad Leithausers skælmske, Sebastian Knigt-agtige rammefortæller i Hence (I989) bruger adskillige komma-streger; Leithauser omtaler også Salman Rushdies "Emily Dickinsonske stormflod af tankestreger" i en anmeldelse i The New Yorker fra samme år - selv om Emily Dickinson måske forekommer en kende malplaceret i sammenhængen. Men vi leger også kun med tanken, vi tre - vi tager ikke vores narrestreger alvorligt; - det kan vi ikke.

Man så meget gerne Malcolm Parkes eller John Lennard (den parentetisk navnkundige) forsøge sig med en gennemarbejdet socialhistorisk studie af den blandede tegnsætnings undergang. En udtømmende forklaring ville uheldigvis være nødsaget til at få det hele med - Gustav Stickley, Henry Ford, Herbert Read, Gertrude Stein, Norbert Wiener, Harold 
Geneen, James Watson, Saint Strunk og i særdeleshed Eleanor Gould på The New Yorker, hvis lette, grå, normative blyantsstreger stadig svæver oven over alting. Og selv herefter ville vi have svært ved at begribe tidehvervets egentlige mikrostruktur. Hvorom alting er, bør vi dagligt takke Malcolm Parkes for at have bibragt os et indblik i den pluralistiske tegnsætnings trivsomme, koralomkransede ti- devandspytter, som gik forud for vores eget renere, mere konsekvente, mere undervisningsfæhigt regelfaste og måske også goldere århundrede.

(I993)

På dansk ved Claus Bech

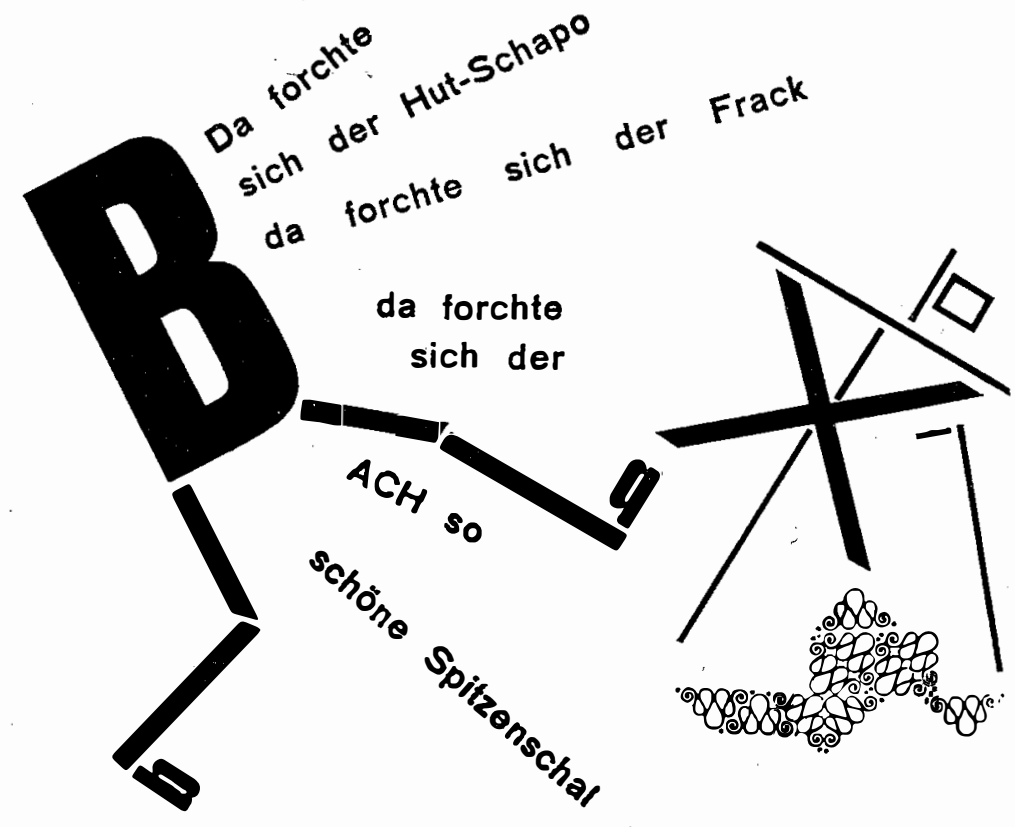

